\title{
Learning to Manage Shame in School Bullying: Lessons for Restorative Justice Interventions
}

\author{
Eliza Ahmed • Valerie Braithwaite
}

Published online: 22 November 2011

(C) Springer Science+Business Media B.V. 2011

\begin{abstract}
Shame management is purported to be part of the healing process that is a goal of restorative justice. However, the development of shame management capacities and how they are engaged in conflict resolution remains a relatively understudied phenomenon. This study examines how shame management (acknowledgment and displacement) is employed by children as they move into and out of cultures of school bullying. The analysis is based on self-reported changes in bullying experiences of 335 Australian children over a threeyear period. Children were classified into bully, victim, bully-victim, nonbully-nonvictim, or residual conflict groups. Shame displacement and bullying tolerance accompanied transition into bullying. Shame acknowledgment and control of bullying marked desistence from bullying. Effects of shame management and social control were not uniform across groups. Findings indicate that interventions to change behaviour need to be flexible and responsive to prior bullying experiences so specific risk and protective factors can be targeted. This study demonstrates that responsiveness to context, building socially responsible relationships, and adaptive shame management are all integral to behaviour change, supporting the use of restorative justice as a way of dealing with school bullying as well as other forms of harm.
\end{abstract}

\section{Introduction}

The principles of restorative justice are based around empowerment, reintegration, restoration and emotional and social healing (Harris 2003). Empowerment for the offender means, in part, building offender accountability. Offenders have an opportunity to take responsibility for what they have done, to make amends to the victim and to become reintegrated into the community. The successful reintegration of the offender depends partly on the victim. Restorative justice empowers victims beyond giving them voice to express the harm they have felt. Those who have been harmed feel empowered through a

E. Ahmed · V. Braithwaite $(\bowtie)$

Regulatory Institutions Network, College of Asia and Pacific, Australian National University, Acton, ACT 0200, Australia

e-mail: Valerie.Braithwaite@anu.edu.au 
sense of being valued and respected. The process communicates belief in their identity as socially responsible individuals who can play a constructive role in restoring justice.

Empowerment of the offender and victim thus opens a pathway for delivering justice. In order for offender and victim to take that pathway, both require a degree of emotional courage. It is not easy for individuals to admit wrongdoing and it is not easy for victims to give permission for offender and victim to move forward constructively. Theoretically, this kind of emotional courage can be understood as shame management (Ahmed et al. 2001).

Within the restorative justice literature, much has been written on the social conditions underpinning shame management (Ahmed et al. 2001; Braithwaite 1989). The term "safe space" has been used to describe the restorative justice context where both victim and offender feel respected and supported, where the harm is the focus of attention, not the perpetrator of the harm, and where there is hope of victim and offender finding a way forward that will address harms, be they material, physical, social or psychological. Less well-understood and investigated is the process by which individuals develop restorative justice "readiness," that is, capacities for shame management as victim or offender that can be accessed productively to deliver justice.

This paper explores the development of shame management in children and the role that it plays in preventing school bullying. Public concern over school bullying has generated considerable debate on preventive measures (Rigby 1996, 2002, 2008). On one side are more conservative voices in the community in favour of social control, punishment, suspension and expulsion of children who bully. On the other side are more progressive voices favouring a more restorative justice and rehabilitative approach. Most anti-bullying programs adopt a mixture of control measures and relationship building and reparation strategies. Farrington and Ttofi (2009) have published an impressively extensive and ambitious meta-analysis of 44 evaluations of anti-bullying programs from across the world. They conclude that school-based anti-bullying programs reduce bullying on average by $20-23 \%$ and decrease victimization by $17-20 \%$. The elements of programs that are effective in the Farrington and Ttofi study are those relating to control of children's behaviour, primarily external controls by authority. Farrington and Ttofi (2009) are less optimistic that investing in relationship building and social responsibility are worthwhile pursuits, particularly among younger children.

Without disputing the desirability of exercising greater control in schools, we contend that developing from the earliest possible age the capacity to manage emotions, particularly shame, underlies the capacity to exercise social responsibility and deal constructively with relationship breakdown later on. Furthermore, we contend that children can and do learn to manage shame in their own time. Such learning may be neither easy nor immediate. It may take a number of anti-bullying or restorative justice interventions along with maturation, personal development and changes in the child's environment for shame management to take place. Using longitudinal data, the purpose of this study is to test these predictions, investigating whether changes in shame management skills account for variability in bullying/victimization behaviour.

\section{Shame Management Theory}

The management of shame has been subject to close scrutiny among children who bully and those who are victims (Ahmed 2001, 2006; Ahmed and Braithwaite 2004a, b, 2005, 2006). Shame is discharged through a range of visible responses-sadness, remorse, regret, humiliation, anger with and withdrawal from others (Lewis 1971; Nathanson 1997; Scheff and Retzinger 1991; Tomkins 1987). The reason why shame generates such painful 
responses is that it reflects an assault on the individual's ethical identity (Harris 2007). The individual feels shame when a gap emerges between beliefs about oneself and one's values on the one hand, and actions on the other. In the bullying context, most children don't believe that bullying is a good thing and that hurting others is acceptable. ${ }^{1}$ When they are caught doing so or are accused of doing so or become aware through other channels of causing harm, a discrepancy is exposed between their ethical identity and their observed behaviour. Shame is felt and the feeling needs to be discharged or resolved.

According to shame management theory, different people handle shame in different ways. Feelings of shame are managed in a socially adaptive way if individuals are able to acknowledge them and work out a way of "making their peace" with those they harm or offend. ${ }^{2}$ Shame can also be managed in less socially adaptive ways. Of most significance is deflection of shame feelings onto others so as to escape any personal negative consequences. Denigrating victims, blaming others, rationalizing and finding other external factors to excuse what happened are all examples of a person avoiding confronting their feelings of shame. Not surprisingly, deflecting responsibility inappropriately risks escalating rather than dampening interpersonal conflict.

These two dimensions of shame management are referred to as acknowledgment and displacement. Acknowledgment involves acknowledging wrongdoing and harm and wishing to make amends. Displacement involves blaming others or external factors. Shame acknowledgment has been associated with less bullying and with a lowering of bullying over time. Displacement has been associated with more bullying and increases in bullying over time (Ahmed 2001, 2006; Ahmed and Braithwaite 2004a, b, 2006; Braithwaite et al. 2003; Shin 2006).

Shame acknowledgment and displacement have been conceptualised as different, but not incompatible, strategies for managing shame that are responsive to context. Acknowledging wrongdoing depends on individuals judging their own actions as harmful, accepting a message from those they respect that their actions are harmful, and feeling that they are in a safe space for admitting to the harm they have done (Ahmed et al. 2001). Under these circumstances, a threat to ethical identity becomes real but also manageable. Displacement is a more likely response than acknowledgment when threat to ethical identity is high with no obvious path to safety.

Such contextual determinants of acknowledgment and displacement mean that theoretically individuals are capable of doing both: Displacing and acknowledging are not mutually exclusive responses. In school environments, for instance, where there is a shared understanding of how bullying can harm others, a response of shame acknowledgment from a child involved in a bullying encounter may be readily elicited. But children can quickly move to displacement if they think their own grievance has been unfairly dealt with or if they feel resentful over being reprimanded. As the social dynamics change in the exchanges between the individual, peers and authority, acknowledgment may give way to

\footnotetext{
1 Data from the Life at School Survey (Ahmed 2001): 6\% of children thought it was OK to hurt someone who bothered them and $2 \%$ said that bullying did not cause harm. Eighty-two percent thought bullying caused moderate or very much harm.

2 There is no assumption within shame management theory that acknowledgment is necessarily the normatively correct position. Sometimes social expectations are to be challenged, not accepted. In the case of bullying, however, a basic tenet of our research is that bullying involves domination of another and such domination is morally unacceptable. Therefore, acknowledging that one has bullied another is a normatively appropriate response, while displacement is an inappropriate response. For victims, excessive shame acknowledgment with a particular focus on self-critical thoughts is normatively undesirable.
} 
displacement and vice versa as the threat to a person's ethical identity and options for dealing with that threat fluctuate.

The above also raises questions about more extreme contexts. What happens when there is no agreed school norm against bullying? A cultural context of this kind blocks the operation of shame management (or any self-regulatory process) because the action that has produced harm is not considered "harmful". In such cases, as unlikely as they are, children may genuinely not realise that there is anything wrong with bullying and shame may be a less relevant emotion as a result.

\section{Personality and Shame Management}

While shame acknowledgment and shame displacement in response to school bullying are regarded as situational responses, there may be a role for more enduring personality dispositions. Some individuals may be consistently less robust and therefore less willing to expose their ethical identity to the threat of wrongdoing. Personality may prevent children from developing the capacity to reflect on their wrongdoing and develop the capacity to regulate their desire to displace shame and favour a pathway of shame acknowledgment.

There is some evidence that more enduring personality characteristics are associated with being a perpetrator and victim of bullying (Björkqvist et al. 1982; Olweus 1993; Slee and Rigby 1993). Personality may lock children into bullying and victim roles, making social control the only viable means of bullying prevention. Impulsivity is a personality characteristic that predisposes some children to behavioural problems, including bullying (Björkqvist et al. 1982; Slee and Rigby 1993). Low self-esteem is another characteristic that can be enduring, particularly when associated with unhappiness and frustration over lack of achievement at school (O’Moore and Hillery 1991; Rigby and Cox 1996; Slee and Rigby 1993). Persistent feelings of unworthiness may invite self-blame and victimization or on the other hand may lead individuals to deflect such feelings by hitting out at others (Kumpulainen et al. 1998; Olweus 1994). High impulsivity and low self-esteem have been associated with bullying in past work using these data (Ahmed 2001; Ahmed and Braithwaite 2004b).

Tangney and her colleagues (Tangney 1990; Tangney et al. 1992) have used the term shame-proneness to describe individuals who become overwhelmed by their own feelings of personal inadequacy when they make a mistake. The mistake mushrooms into a symbol of global personal failure. As a consequence, such children become consumed by their own lack of self-worth and are unable to move on to make amends and put their mistake behind them. Tangney et al. contrast shame-proneness to guilt-proneness where individuals are able to focus on the mistake they have made without denigrating their whole self and thereby acknowledge the harm caused to others and make amends. A third enduring characteristic described by Tangney et al. involves externalization, i.e., blaming others for mistakes that are made. While shame-proneness may predispose individuals to internalise blame and be more vulnerable to victimization, the enduring characteristics of externalisation and guilt-proneness resemble the shame management strategies of displacement and acknowledgment respectively (Ahmed 2001), and may be the source of persistence in bullying and desistence from bullying for some groups.

\section{The Present Study}

This study examines the bullying history of children over a three-year period and how their paths are influenced by shame acknowledgment and displacement, bullying tolerant school norms, impulsivity, shame-proneness, guilt-proneness and externalization. Five groups of 
children were tracked over the 3 years: bullies, victims, bully-victims, nonbully-nonvictims, and those embroiled in residual conflict. In this way, we are able to test the selfregulatory significance of shame management-which is thought to be a key mechanism in restorative justice processes - outside of the restorative justice context, as children moved into and out of bullying.

The three-year time span of this study provided opportunity for children to develop their shame management capacities at their own pace. Children moved from primary school to high school during this period, giving them time to experience a new school environment, to engage in a bullying episode first hand as bully or victim, and to try out their shame management capacities for resolving bullying conflicts.

In addition, we tested the importance of context and personality. Given that children had moved from primary school to high school, the data are well suited to testing whether a change of environment, specifically school tolerance surrounding bullying, is associated with a change in role status as bully or victim. With change in school and maturation, these data also provide an ideal opportunity for asking whether personality dispositions dominate other factors in the years when we might expect children to be acquiring shame management capacities.

A special feature of the analyses presented in this paper is that we have focused on comparing how children in different circumstances use their shame management capacities. In previous work, we have tested the concurrent relationship between shame management strategies and different bullying groups of children (Ahmed et al. 2001). We have also tested the extent to which shame management, personality dispositions, and perceptions of a bullying tolerant culture predict bullying behaviour using path analyses and regression models (see Ahmed 2001, 2006; Ahmed and Braithwaite 2004a, b; Braithwaite et al. 2003). These prior analyses show shame management having net effects beyond personality and bullying school cultures, but as Farrington and Ttofi's (2009) study suggests, this may not translate into shame management being a point of leverage for healing in anti-bullying programs or restorative justice conferences. Particular groups such as bullies, bully-victims and victims may employ different shame management strategies, leading to different outcomes of a given intervention across these groups. Similarly, different personality characteristics and bullying school cultures may also affect the success of interventions. It is important to investigate whether shame management, personality characteristics, and bullying culture impact children's transitions into and out of antisocial behaviour over time. Therefore, the analyses in this paper explicitly test this question: Do children whose behaviour changes over time (either from antisocial to pro-social or vice versa) differ from those children whose (antisocial or pro-social) behaviour does not change over time, with regard to their shame management strategies, personality characteristics, and school bullying culture? By comparing the shame management strategies, personality characteristics and bullying cultures across the five groups of participants in our study, we can determine whether anti-bullying interventions that are relationship oriented, and restorative justice interventions more broadly, need to be sensitive to these differences in shame management strategies, personality, and cultural norms.

\section{Method}

Participants

The initial sample (T1) was drawn from 32 public and private schools in Canberra, Australia, in 1996 through an invitation to parents and children to take part in the "Life at 
School Survey" (for details, see Ahmed 2001). All these schools were co-educational. Participation was voluntary.

This first wave of data (T1) involved 1,402 children, $46 \%$ boys, $54 \%$ girls. The sample was drawn from students in grades four to seven: $15 \%$ were in fourth grade (9-10 years); $40 \%$ in fifth grade (10-11 years); $40 \%$ in sixth grade (11-12 years); and 3\% in seventh grade (11-12 years). The mean age of the student sample was 10.86 years $(\mathrm{SD}=.90)$.

The assumption underlying the measurement of bullying and victimization was that there would be degrees of exposure to the phenomenon. Twenty-eight percentage of children reported that they had not been bullied in the past 12 months, $45 \%$ had been bullied now and again, and 27\% more often. When children were asked about bullying others, $46 \%$ had never bullied as part of a group, $37 \%$ said they had done so once or twice, and $17 \%$ had bullied as part of a group sometimes or more often. In response to how often they had bullied on their own, 67\% said they had never bullied alone, 24\% said once or twice, and $9 \%$ said sometimes or more often. The prevalence of bullying and victimization was on a par with the Australian findings of Rigby (1996).

Of the original sample, $581(59 \%)$ agreed to participate in a follow-up survey 3 years later (T2). At T2, questionnaires were returned by 335 children- $48 \%$ boys, $52 \%$ girls, who provided details of their school experiences. Despite the high attrition rate, there was little change in the breakdown of the sample in terms of key social demographic indicators (Ahmed 2001). The main reason for non-response was inability to make contact with the family, followed by failure to return questionnaires, due mainly to adolescent children not wanting to spend their spare time filling out a questionnaire. By the time data collection at T2 was underway, most children had made the transition to high school. Their average age in years at T2 was $13.5(\mathrm{SD}=.86)$ with $17 \%$ in Grade $7,42 \%$ in Grade $8,38 \%$ in Grade 9, and $4 \%$ in Grade 10. At T2, 48\% had not been bullied in the past year, 39\% now and again and $13 \%$ more often. In terms of bullying others in the past 12 months, 39\% had not bullied anyone as part of a group, 39\% bullied as part of a group now and again and $22 \%$ bullied as part of a group more often. $68 \%$ had not bullied anyone alone, $23 \%$ only did so now and again and $8 \%$ did so more often.

The sample used for the analyses in this paper comprised 335 children who took part in the "Life at School" survey at both T1 and T2. The parent who gave consent for the child's participation was the mother in most cases (90\%). Children with at least one non-Australian parent comprised $24 \%$ of the sample, with $14 \%$ having at least one parent from a non-English speaking country. The education level achieved by parents was high: $35 \%$ had a university degree. Paid employment was entered into by $77 \%$ of primary caregivers in 1996 and $82 \%$ in 1999.

\section{Measures}

\section{Bullying Group Status}

Children were asked to self-identify how often they were bullied and how often they had bullied others individually or as part of a group. Before the questions were asked, the following definition of bullying based on Olweus (1993) was given to respondents: "We call it bullying when someone repeatedly hurts or frightens someone weaker than themselves on purpose. It is not bullying when two young people of about the same strength have the odd fight or quarrel. Bullying can be done in different ways: by hurtful teasing, threatening actions or gestures, name-calling, or hitting or kicking." 
Children were classified into one of five bullying status groups-bully, victim, bullyvictim, nonbully-nonvictim, or residual conflict group. There was no a priori assumption that the groups would be distinctive; rather the purpose of the exercise was to empirically test whether the dispositional and social factors previously associated with change in bullying status over time acted differently in relation to these subgroups. The classification was made using children's answers on five questions (based on Rigby and Slee (1993) and the Peer Relations Questionnaire; for a discussion of validity checks, see Ahmed 2001). ${ }^{3}$

In order to assess participation in bullying, the following three questions were asked:

a. How often have you been a part of a group that bullied someone during the last year? Response options were: (1) never (46\% at T1 and 39\% at T2); (2) once or twice (37\% at $\mathrm{T} 1$ and $39 \%$ at T2); (3) sometimes (13.5\% at T1 and $16 \%$ at T2); (4) once a week ( $2 \%$ at $\mathrm{T} 1$ and $4.5 \%$ at $\mathrm{T} 2$ ); or (5) several times a week (1.5\% at both $\mathrm{T} 1$ and $\mathrm{T} 2$ ).

b. How often have you, on your own, bullied someone during the last year? The same response options were used as above: (1) never (67\% at T1 and 68.5\% at T2); (2) once or twice (24\% at T1 and $23 \%$ at T2); (3) sometimes (7\% at $\mathrm{T} 1$ and $6 \%$ at $\mathrm{T} 2$ ); (4) once a week (1\% at $\mathrm{T} 1$ and $1.5 \%$ at $\mathrm{T} 2)$; or (5) several times a week (1\% at both $\mathrm{T} 1$ and $\mathrm{T} 2)$. Those who responded with any answer other than "never" were asked:

c. Why did you think you bullied that child? Was it to get even? Of those children who had reported that they had bullied someone, 50\% said it was to get even at T1 and $44 \%$ at $\mathrm{T} 2$.

Children were classified as part of the bully group if they had, on at least one occasion, bullied another as part of a group or individually without the purpose of getting even. In order to assess being a victim of bullying, another two questions were asked:

d. Looking back over your life at school in the past year, how often have you been bullied by another student or group of students? Response options were: (1) most days (7\% at $\mathrm{T} 1$ and $2.5 \%$ at T2); (2) one or 2 days a week (6\% at T1 and $3 \%$ at T2); (3) about once a week (5\% at T1 and $3.5 \%$ at T2); (4) about once every few weeks (8\% at T1 and $4 \%$ at T2); (5) every now and again (45\% at T1 and 39\% at T2); or (6) never (29\% at T1 and $48 \%$ at $\mathrm{T} 2$ ). This index was reverse scored such that a high score indicated high frequency of experienced victimization.

Those who responded that they were "never" bullied were asked:

e. Why do you think you were bullied? Did you do something hurtful to someone? Of those children who had reported that they had been the victim of bullying, $11 \%$ agreed that they had hurt someone first at $\mathrm{T} 1$ and $9 \%$ at $\mathrm{T} 2$.

Children were classified as part of the victim group if they had on at least one occasion been the victim of bullying without their hurting the person who bullied them first.

As a result of this classification process, three groups were constructed: a bully group (bullies, not victims), a victim group (victims, not bullies) and a bully-victim group (both

\footnotetext{
${ }^{3}$ Measurement of bullying in this study is through self-definition and questionnaires. Parents were also asked to report on their children's bullying experiences as a way of providing some validation of the measures used (Ahmed 2001). While we have used our measures as continuous variables in most of our research, we have dichotomized variables and formed groups on past occasions (see Ahmed 2001, 2006). In this study we have used slightly different criteria than used in the past in response to criticism of the distinctiveness of the groups (Finger et al. 2005). More recently, multi-item interval scales have been recommended to assess degree of bullying in terms of frequency of occurrence and type of bullying action (Finger et al. 2005). These developments undoubtedly give a more fine-grained procedure for assessing bullying than that used here, although they do not provide a solution to the important problem of when for a child, cussing and joshing turn into bullying. Bullying remains a highly subjective phenomenon: One child's play is another child's terror.
} 
bullies and victims). The remainder of the sample were divided into a nonbully-nonvictim group and a residual group. The nonbully-nonvictim group responded "never" to Questions 1, 2 and 4 above. The residual group comprised children who replied yes to bullying or victimization in Questions 1, 2 and 4 above, and who also answered yes to Questions 3 and 5, agreeing that they provoked the incident or were retaliating. In this paper, the residual group has been separated out because bullying is more stringently defined as action that seeks to dominate and disempower others psychologically or physically without provocation. The breakdown of these groups at $\mathrm{T} 1$ and $\mathrm{T} 2$ is reported in the results.

\section{Management of Shame State: Shame Acknowledgment and Shame Displacement (MOSS-SASD)}

The MOSS-SASD provides children with eight scenarios, each describing a bullying incident at school. Four of these scenarios were used at both T1 and T2 and are described in the "Appendix". In each scenario, the wrongdoer hurts another child (physically or socially), and is caught doing so by an authority figure such as his or her teacher. Children are asked to imagine being the wrongdoer in these scenarios.

After reading each scenario, the children were asked to tick the box (yes $=2$, no $=1$ ) that best represented their answer to each of ten questions that assessed ten facets of shame management, five representing acknowledgment, five displacement (for item details, see Ahmed 2001). After a series of reliability and validity analyses, four acknowledgment dimensions and four displacement dimensions were taken forward for subsequent analysis. The four acknowledgment dimensions were: (1) feeling shame; (2) hiding self; (3) taking responsibility; and (4) making amends. The four displacement dimensions were: (1) blaming others; (2) feeling angry; (3) getting even (retaliatory anger); and (4) kicking or hitting at someone or something else (displaced anger).

Composite shame acknowledgment and displacement scores were calculated by averaging across the four scenarios for each dimension. The alpha reliability coefficients based on the four scores that made up shame acknowledgment were .67 at T1 and .78 at T2. The scale means were 1.82 at $\mathrm{T} 1$ and 1.77 at $\mathrm{T} 2(\mathrm{SD}=.23$ and .26 , respectively). The alpha reliability coefficients for the shame displacement scale were .62 at T1 and .68 at T2. The scale means were 1.21 at $\mathrm{T} 1$ and 1.10 at $\mathrm{T} 2$ ( $\mathrm{SD}=.23$ and .16 , respectively). Higher scores represented higher acknowledgement and higher displacement.

\section{Perceptions of a Bullying Tolerant Culture}

This measure consisted of 7 items taken from the Peer Relations Questionnaire (Rigby and Slee 1993). Students answered the following two questions on a 4-point rating scale: (1) In your view, is this school a safe place for young people who find it hard to defend themselves from attack from other students? (2) Do you think that teachers at this school are interested in trying to stop bullying?

Five additional questions with a 3-point response format were: (3) How often would you say that bullying happens at this school? And have you noticed bullying going on in this school in any of these places?: (4) in the classroom; (5) at recess/lunch; (6) on the way to school; and (7) on the way home from school. Items were scored so that higher scores indicated that students perceived their school as more bullying tolerant. Because of differences in the response categories of the items, item scores were standardized to a mean of 0 and a standard deviation of 1 before being averaged to form a measure of a perceived bullying tolerant culture $(\mathrm{M}=.00 ; \mathrm{SD}=.57 ; \alpha=.66)$. 


\section{Personality Measures}

The following scales were used to assess personality characteristics that theoretically may explain why children are drawn into and caught in cycles of bullying and victimization. The measures used in the subsequent analyses were all taken at T1.

Shame-proneness, guilt-proneness and externalization were part of a scenario-based measure developed by Tangney (1990) in which she presented fifteen pictures of children making mistakes of various kinds. Children were provided with sets of possible responses tailored to the particular situation. In relation to each possible response they indicated how likely it was that they would act in that way on a 5 point rating scale (very unlikely to very likely) with a high score indicating high likelihood.

Shame-proneness had an alpha reliability of .82, a mean of 2.88 , and a standard deviation of .65. Guilt-proneness had an alpha reliability of .83 , a mean of 3.72 , and a standard deviation of .60. Externalization had an alpha reliability of .67, a mean of 2.69 , and a standard deviation of .49 .

Impulsivity was measured by 3 items: (1) I often get involved in things I later wish I could get out of; (2) I often get into trouble because I do things without thinking; (3) I often do and say things without stopping to think. The participants responded to each statement on a 4-point scale ranging from 'disagree a lot' (1) to 'agree a lot' (4). The alpha reliability coefficient for the impulsivity scale was .67 with a mean of 2.78 and a standard deviation of .73. Higher scores reflected less impulse control.

\section{Procedure}

At T1, students who had been given written permission to participate by a parent or guardian completed their questionnaires during school hours. The survey took approximately 25-40 min to complete for the older groups, and 35-65 min for the younger groups. The researchers were present as the survey was completed and were on hand to assist children having difficulty with any of the questions. The students also took a survey home for their parents to complete. On the last page of the parent survey, families who were willing to take part in a follow-up survey were asked to provide their name and address.

At T2, questionnaires were mailed out to those families who expressed their willingness to participate in a follow-up "Life at School Survey". Shorter versions of the original questionnaires (both a child version and a parent version) were used at T2. Both parents and students were asked to return their completed questionnaires separately in sealed envelopes to the researchers by reply paid post.

\section{Results}

\section{Analysis Strategy}

Data analyses proceeded in two steps: (1) bullying status at T1 was cross-tabulated against bullying status at T2 to ascertain patterns of stability and change over 3 years; and (2) groups with different bullying trajectories over the 3 years were compared in terms of their mean scores on shame acknowledgment and displacement (T1 and T2), perceptions of a bullying tolerant culture (T1 and T2), and personality dispositions of impulsivity, shameproneness, guilt-proneness, and externalization (T1). All statistical analyses were conducted using SPSS Version 17. 
Cross-Tabulation of Bullying Status at T1 and T2

The relationship between bullying status at T1 and bullying status at T2 was statistically significant using a Chi-square test of independence $\left(\chi^{2}(16, \mathrm{n}=333)=86.03, p<.001\right)$, with most children in T2 being in the same group they belonged to at T1. Nevertheless, there was some movement between groups. Patterns of stability and change have been reported in previous research (Chappell et al. 2006; Schäfer et al. 2005; Sourander et al. 2000; Wolke et al. 2009). Gaining insights into how individuals move and why has been regarded as important for successful interventions (Hanish and Guerra 2004). The movement can be summarized as follows:

1. If $\mathrm{T} 1$ bullies did not continue as bullies at $\mathrm{T} 2$, they were most likely to fall into the nonbully-nonvictim group.

2. If the $\mathrm{T} 1$ nonbully-nonvictims became engaged in bullying at $\mathrm{T} 2$, they were most likely to do so as bullies.

3. T1 victims were spread more evenly across the bully status groups at T2.

4. T1 bully-victims varied in their T2 destinations, but if they moved they were most likely to become bullies.

5. The T1 residual group, if they moved, were most likely to become part of the bullying group at $\mathrm{T} 2$.

The number in each cell in Table 1 tends to be on the small side (the sample is small for this analysis with a minimum expected cell frequency of 6), demanding caution in any statistical inferences we may draw. Some general trends, nevertheless, are interesting to observe. Overall, these findings show a trend toward staying in one's bully status group from $\mathrm{T} 1$ to $\mathrm{T} 2$ with most movement in the direction of the bully group.

\section{Comparing Histories from $\mathrm{T} 1$ to $\mathrm{T} 2$ on the Independent Variables}

The next set of analyses was conducted for each of the T1 bullying status groups separately - bully, victim, bully-victim, nonbully-nonvictim and residual conflict. The question asked was: Do children whose classification (bully, victim, etc.) changes from T1 to T2 differ from those children whose classification does not change over time, with regard to their shame management strategies, bullying culture, shame proneness, guilt proneness, externalisation and impulsivity? Given the small numbers in some cells in Table 1, analyses were conducted to compare those who stayed in each T1 classification at T2, against those who moved from the T1 classification to the next most common T2 destination. (Usually this meant comparing two destinations, except for the T1 victim group.) The groups that were compared in the following analyses appear in the rows in bold in Table 1.

\section{Bullies at T1: Bully or Nonbully-Nonvictim at T2}

The first set of group comparisons examined the independent variables that differentiated those who were locked into bullying (i.e. who were bullies at both T1 and T2) and those who became nonbully-nonvictims (i.e. who were bullies at $\mathrm{T} 1$ and nonbully-nonvictims at T2).

A series of independent t-tests was used to ask whether those who moved out of the bully group into the nonbully-nonvictim group acknowledged shame more, displaced shame less, and were less immersed in a bullying school culture. $T$ tests were also included 
Table 1 T2 bullying status percentage distributions for children from each T1 bullying status group (row percentages and numbers in bold are used for statistical comparisons)

\begin{tabular}{lllllc}
\hline T1 bullying status group & \multicolumn{5}{c}{ T2 bullying status group } \\
\cline { 2 - 6 } & Bully & Victim & $\begin{array}{l}\text { Bully- } \\
\text { victim }\end{array}$ & $\begin{array}{l}\text { Nonbully- } \\
\text { nonvictim }\end{array}$ & $\begin{array}{l}\text { Residual } \\
\text { conflict }\end{array}$ \\
\hline Bully $(\mathrm{n}=38)$ & $\mathbf{4 7 . 4 ( 1 8 )}$ & 7.9 & 13.2 & $\mathbf{2 1 . 1}(\mathbf{8})$ & 10.5 \\
Victim $(\mathrm{n}=89)$ & $\mathbf{2 0 . 2}(\mathbf{1 8})$ & $\mathbf{3 2 . 6}(\mathbf{2 9})$ & $\mathbf{1 9 . 1}(\mathbf{1 7 )}$ & $\mathbf{1 9 . 1}(\mathbf{1 7})$ & 9.0 \\
Bully-victim $(\mathrm{n}=68)$ & $\mathbf{2 3 . 5}(\mathbf{1 6})$ & 14.7 & $\mathbf{3 2 . 4}(\mathbf{2 2})$ & 14.7 & 14.7 \\
Nonbully-nonvictim $(\mathrm{n}=56)$ & $\mathbf{3 5 . 7}$ & 7.1 & 8.9 & $\mathbf{4 1 . 1}$ & 7.1 \\
Residual conflict & $\mathbf{2 6 . 9}(\mathbf{2 1})$ & 10.3 & 17.9 & 7.7 & $\mathbf{3 7 . 2}(\mathbf{2 9})$ \\
\hline
\end{tabular}

$\chi^{2}(16, \mathrm{n}=333)=86.03, p<.001$

Table 2 Mean scores and $t$ values comparing the T1-T2 bully group with the T1 Bully-T2 nonbullynonvictim group

\begin{tabular}{lllc}
\hline Independent variables & \multicolumn{2}{c}{$\mathrm{M}(\mathrm{SD})$} & \multirow{2}{*}{ values } \\
\cline { 2 - 3 } & $\mathrm{T} 2$ bully $(\mathrm{n}=18)$ & $\mathrm{T} 2$ nonbully-nonvictim $(\mathrm{n}=8)$ & \\
\hline Shame management & & & \\
T1 acknowledgment & $1.66(.33)$ & $1.77(.21)$ & -.86 \\
T1 displacement & $1.14(.20)$ & $1.19(.20)$ & -.55 \\
T2 acknowledgment & $1.53(.35)$ & $1.86(.14)$ & $-3.50^{* *}$ \\
T2 displacement & $1.11(.12)$ & $1.11(.13)$ & -.01 \\
Bullying culture & & & \\
T1 Perceived bullying tolerant culture & $1.82(.31)$ & $1.54(.19)$ & $2.71^{*}$ \\
T2 Perceived bullying tolerant culture & $1.91(.41)$ & $1.58(.51)$ & 1.80 \\
Personality (T1) & & & -1.34 \\
Shame-proneness & $2.50(.60)$ & $2.87(.72)$ & -.84 \\
Guilt-proneness & $3.44(.93)$ & $3.66(.41)$ & .68 \\
Externalization & $2.75(.55)$ & $2.59(.53)$ & 1.11 \\
Impulsivity & $3.02(.62)$ & $2.67(.92)$ & \\
\hline
\end{tabular}

$* p<.05, * * p<.01$

to check for personality differences between the groups at $\mathrm{T} 1$. Bivariate rather than multivariate statistical tests were used in this case, as in the cases that follow, because of the small sample sizes.

The results in Table 2 show that those who stayed in the bullying group were less able to acknowledge shame at T2 than those who moved to the nonbully-nonvictim group. Moreover, those who stayed in the bullying group rather than moving out had a history of their earlier bullying experiences occurring in a bullying tolerant culture. Personality factors did not appear to explain who among the T1 bullies remained in the bullying group and who moved into the nonbully-nonvictim group. For these groups, the critical events seemed to be observing that bullying was not acceptable at school at T1 and acknowledging shame over bullying at $\mathrm{T} 2$. 


\section{Victims at T1: Diverse Destinations at T2}

Those who were victims at $\mathrm{T} 1$ were dispersed across bullying status groups at $\mathrm{T} 2$. Of particular interest were those who moved into the bullying role rather than staying in the victim role. They could do this by joining the bully-victim group or the bully group.

A set of one-way analyses of variance compared T1 victims who belonged to the T2 victim group, the $\mathrm{T} 2$ bully group, the $\mathrm{T} 2$ bully-victim group, and the T2 nonbully-nonvictim group on shame management, perceptions of a bullying tolerant culture, and personality. Those $\mathrm{T} 1$ victims who became $\mathrm{T} 2$ nonbully-nonvictims were included in this analysis because this $\mathrm{T} 2$ destination was as common for $\mathrm{T} 1$ victims as were the $\mathrm{T} 2$ groups that featured bullying. Where a significant $F$ value emerged from the analysis of variance, Fisher's least significant difference test was used to compare pairs of means.

From Table 3, those who made the move from being a T1 victim to being a T2 bully had significantly higher shame displacement scores at $\mathrm{T} 2$ than those who remained part of the victim group, or who moved to the bully-victim group or the nonbully-nonvictim group.

From Table 3, those T1 victims who moved to nonbully-nonvictim status at T2 differed from those who moved to bully or bully-victim status at $\mathrm{T} 2$, in terms of perceptions of a bullying tolerant culture at $\mathrm{T} 2$. Those $\mathrm{T} 1$ victims who became nonbully-nonvictims perceived less school tolerance for bullying at $\mathrm{T} 2$ than did those $\mathrm{T} 1$ victims who moved into the bullying categories. The options for T1 victims were in part shaped by experiences of the safety of the school at T2, and in part by a willingness later on to embrace a bullying and shame displacing culture. It appears that in some cases, the best option was "if you can't beat them, join them".

\section{Bully-Victims at T1: Bully-Victim or Bully at T2}

Those who were both bullies and victims at T1 were most likely to have the same status at T2 (i.e. they were bully-victims at both T1 and T2), although some had moved to the group who bullied without being victimized (i.e. they were bully-victims at T1 and bullies at T2).

A series of independent $t$ tests was used to test whether those T1 bully-victims who moved to the bully group were different from those who remained bully-victims in terms of shame management, perceptions of a tolerant bullying culture and personality dispositions. From Table 4, those who moved to the bully group were distinctive on only one measurethey experienced less guilt over wrongdoing on Tangney's personality scale at T1 than those who remained in the bully-victim group at $\mathrm{T} 2$.

\section{Residual Conflict at T1: Residual Conflict or Bully at T2}

The residual conflict group comprised mainly children who bullied to get even. They may or may not have felt victimized. Their bullying status was determined solely in terms of how they described their situation so it was of interest to find out if they had changed their T1 self-definition by T2 and if so, how. Surprising stability was found in this group given that it was a residual category, but equally surprising was that children who were in this group at $\mathrm{T} 1$ were more likely to move to being a bully or bully-victim at $\mathrm{T} 2$ than out of the bullying culture altogether (from Table 1).

A series of independent $t$ tests comparing those who remained in the residual conflict group and those who became bullies at $\mathrm{T} 2$ pointed to one significant difference, shown in 
Table 3 Mean scores and $F$ values comparing the T1-T2 victim group with the T1 victim-T2 bully-victim group, T1 victim-T2 bully group, and T1 victim-T2 nonbully-nonvictim group

\begin{tabular}{|c|c|c|c|c|c|}
\hline \multirow[t]{2}{*}{ Independent variables } & \multicolumn{4}{|c|}{$M(S D)$} & \multirow[t]{2}{*}{$F$ values } \\
\hline & $\begin{array}{l}\text { T2 victim } \\
(\mathrm{n}=29)(\mathrm{a})\end{array}$ & $\begin{array}{l}\text { T2 bully-victim } \\
(\mathrm{n}=17)(\mathrm{b})\end{array}$ & $\begin{array}{l}\text { T2 bully } \\
(\mathrm{n}=19)(\mathrm{c})\end{array}$ & $\begin{array}{l}\text { T2 nonbully- } \\
\text { nonvictim }(\mathrm{n}=18) \\
\text { (d) }\end{array}$ & \\
\hline \multicolumn{6}{|l|}{ Shame management } \\
\hline T1 acknowledgment & $1.82(.18)$ & $1.91(.12)$ & $1.82(.22)$ & $1.90(.17)$ & 1.50 \\
\hline T1 displacement & $1.14(.18)$ & $1.09(.12)$ & $1.26(.28)$ & $1.14(.24)$ & 2.13 \\
\hline $\mathrm{T} 2$ acknowledgment & $1.88(.14)$ & $1.87(.19)$ & $1.76(.27)$ & $1.91(.14)$ & 2.44 \\
\hline $\mathrm{T} 2$ displacement & $1.06^{\mathrm{c}}(.11)$ & $1.06^{\mathrm{c}}(.11)$ & $1.25^{\mathrm{abd}}(.23)$ & $1.08^{\mathrm{c}}(.15)$ & $6.54 * * *$ \\
\hline \multicolumn{6}{|l|}{ Bullying culture } \\
\hline $\begin{array}{l}\text { T1 Perceived bullying } \\
\text { tolerant culture }\end{array}$ & $1.83(.38)$ & $1.74(.29)$ & $1.87(.27)$ & $1.64(.28)$ & 1.80 \\
\hline $\begin{array}{l}\text { T2 Perceived bullying } \\
\text { tolerant culture }\end{array}$ & $1.86(.48)$ & $2.07^{\mathrm{d}}(.29)$ & $1.96^{\mathrm{d}}(.41)$ & $1.67^{\mathrm{bc}}(.43)$ & $2.97 *$ \\
\hline \multicolumn{6}{|l|}{ Personality (T1) } \\
\hline Shame-proneness & $3.04(.72)$ & $2.96(.44)$ & $3.14(.54)$ & $3.04(.71)$ & .26 \\
\hline Guilt-proneness & $3.91(.61)$ & $3.86(.31)$ & $3.96(.38)$ & $3.78(.44)$ & .51 \\
\hline Externalization & $2.56(.54)$ & $2.60(.41)$ & $2.79(.46)$ & $2.69(.50)$ & 1.00 \\
\hline Impulsivity & $2.41(.56)$ & $2.83(.85)$ & $2.67(.64)$ & $2.26(.75)$ & 2.50 \\
\hline
\end{tabular}

Superscripts refer to groups (a, b, c, d from left to right) and indicate significant differences with other groups' means. A superscript $\mathrm{c}$ for the mean score on group a signifies that "group a mean" differs significantly from "group c mean" at a .001 level of significance

$* p<.05, * * * p<.001$

Table 4 Mean scores and $t$ values comparing the T1-T2 bully-victim group with the T1 bully-victim-T2 bully group

\begin{tabular}{|c|c|c|c|}
\hline \multirow[t]{2}{*}{ Independent variables } & \multicolumn{2}{|c|}{$\mathrm{M}(\mathrm{SD})$} & \multirow[t]{2}{*}{$t$ values } \\
\hline & T2 bully-victim $(\mathrm{n}=22)$ & T2 bully $(\mathrm{n}=16)$ & \\
\hline \multicolumn{4}{|l|}{ Shame management } \\
\hline T1 acknowledgment & $1.88(.24)$ & $1.70(.32)$ & 1.92 \\
\hline $\mathrm{T} 1$ displacement & $1.17(.18)$ & $1.31(.30)$ & -1.70 \\
\hline $\mathrm{T} 2$ acknowledgment & $1.80(.28)$ & $1.64(.28)$ & 1.74 \\
\hline $\mathrm{T} 2$ displacement & $1.13(.20)$ & $1.10(.16)$ & .58 \\
\hline \multicolumn{4}{|l|}{ Bullying culture } \\
\hline T1 Perceived bullying tolerant culture & $2.00(.37)$ & $1.91(.25)$ & .85 \\
\hline T2 Perceived bullying tolerant culture & $1.94(.26)$ & $1.97(.38)$ & -.26 \\
\hline \multicolumn{4}{|l|}{ Personality (T1) } \\
\hline Shame-proneness & $3.08(.52)$ & $3.08(.75)$ & .04 \\
\hline Guilt-proneness & $3.84(.41)$ & $3.42(.64)$ & $2.47 *$ \\
\hline Externalization & $2.87(.42)$ & $2.84(.52)$ & .22 \\
\hline Impulsivity & $2.86(.77)$ & $2.98(.48)$ & -.53 \\
\hline
\end{tabular}

$* p<.05$ 
Table 5 Mean scores and $t$ values comparing the T1-T2 conflict residual group with the T1 conflict residual-T2 bully group

\begin{tabular}{|c|c|c|c|}
\hline \multirow[t]{2}{*}{ Independent variables } & \multicolumn{2}{|l|}{$\mathrm{M}(\mathrm{SD})$} & \multirow[t]{2}{*}{$t$ values } \\
\hline & T2 residual conflict $(\mathrm{n}=29)$ & T2 bully $(\mathrm{n}=21)$ & \\
\hline \multicolumn{4}{|l|}{ Shame management } \\
\hline T1 acknowledgment & $1.86(.13)$ & $1.74(.26)$ & $2.00 *$ \\
\hline T1 displacement & $1.35(.28)$ & $1.26(.25)$ & 1.21 \\
\hline T2 acknowledgment & $1.67(.26)$ & $1.74(.20)$ & -1.10 \\
\hline T2 displacement & $1.18(.19)$ & $1.12(.20)$ & 1.04 \\
\hline \multicolumn{4}{|l|}{ Bullying culture } \\
\hline T1 Perceived bullying tolerant culture & $1.96(.35)$ & $2.06(.36)$ & -.98 \\
\hline T2 Perceived bullying tolerant culture & $2.01(.31)$ & $1.92(.34)$ & .89 \\
\hline \multicolumn{4}{|l|}{ Personality (T1) } \\
\hline Shame-proneness & $3.13(.50)$ & $2.98(.71)$ & .87 \\
\hline Guilt-proneness & $3.60(.56)$ & $3.67(.52)$ & -.46 \\
\hline Externalization & $2.87(.44)$ & $2.89(.50)$ & -.21 \\
\hline Impulsivity & $3.05(.76)$ & $2.90(.68)$ & .68 \\
\hline
\end{tabular}

$* p<.05$

Table 5: Those who escalated to bullying status acknowledged less shame over bullying at $\mathrm{T} 1$.

\section{Nonbully-Nonvictim at T1: Nonbully-Nonvictim or Bully at T2}

The final set of analyses compared T1 nonbully-nonvictims who stayed out of the bullying culture at T2 as nonbullies-nonvictims, against those who had joined it at T2 as bullies. A series of independent $t$ tests revealed that those who became bullies at T2 acknowledged less shame over bullying and displaced more shame ${ }^{4}$ at $\mathrm{T} 2$, when compared to those who had remained outside the bullying culture (Table 6).

\section{Discussion}

These analyses show that in general, children remained in the same bullying roles over 3 years-as bully, victim, bully-victim, nonbully-nonvictim, or as someone embroiled in residual conflict. Where change occurred, children gravitated toward taking on a role which involved bullying others. The variables that featured significantly in the analyses were not so much personality dispositions but rather the context sensitive measures of shame acknowledgment, shame displacement and perceptions of a bullying tolerant culture. Personality proved to be important in the case of only one group, bully-victims, whereas shame acknowledgment and displacement were important for movement in four of the five groups. A bullying tolerant culture was important in only two of the five groups,

\footnotetext{
4 The items of the displacement measure were almost unanimously rejected by nonbully-nonvictims in 1999. The measure needs to be improved to have greater sensitivity to assess displacement among older, more sophisticated and less overtly aggressive groups.
} 
Table 6 Mean scores and $t$ values comparing the T1-T2 nonbully-nonvictim group with the T1 nonbullynonvictim-T2 bully group

\begin{tabular}{|c|c|c|c|}
\hline \multirow[t]{2}{*}{ Independent variables } & \multicolumn{2}{|l|}{ M (SD) } & \multirow[t]{2}{*}{$t$ values } \\
\hline & T2 nonvictim-nonbully $(\mathrm{n}=23)$ & $\mathrm{T} 2$ bully $(\mathrm{n}=20)$ & \\
\hline \multicolumn{4}{|l|}{ Shame management } \\
\hline T1 acknowledgment & $1.82(.23)$ & $1.89(.11)$ & -1.28 \\
\hline T1 displacement & $1.08(.12)$ & $1.11(.17)$ & -.60 \\
\hline $\mathrm{T} 2$ acknowledgment & $1.82(.27)$ & $1.62(.26)$ & $2.37 *$ \\
\hline T2 displacement & $1.02(.04)$ & $1.14(.21)$ & $-2.44 *$ \\
\hline \multicolumn{4}{|l|}{ Bullying culture } \\
\hline T1 Perceived bullying tolerant culture & $1.56(.36)$ & $1.69(.31)$ & -1.28 \\
\hline T2 Perceived bullying tolerant culture & $1.83(.37)$ & $1.83(.43)$ & .04 \\
\hline \multicolumn{4}{|l|}{ Personality (T1) } \\
\hline Shame-proneness & $2.72(.44)$ & $2.60(.62)$ & .68 \\
\hline Guilt-proneness & $3.80(.53)$ & $3.61(.54)$ & 1.16 \\
\hline Externalization & $2.62(.36)$ & $2.42(.46)$ & 1.54 \\
\hline Impulsivity & $2.39(.60)$ & $2.55(.67)$ & -.82 \\
\hline
\end{tabular}

$* p<.05$

but these were groups of concern: primary school children who were caught up in bullying as bully or victim.

Overall, the findings in this paper are consistent with cross-sectional analyses and with those based on aggregated data analysed across time (Ahmed et al. 2001; Ahmed 2006). They are also consistent with conclusions from other researchers: Context is more important than personality dispositions in explaining who becomes caught up in a bullying culture (Espelage et al. 2000). The value that these data add is an appreciation of how shame management and perceived bullying tolerance lead some into the bullying culture and allow others to move out, but this depends on their current experiences of bullying and victimization, and institutional responses to them. It is clear from these data that teaching children shame management capacities in primary school is not going to be an immediate panacea for bullying. But at some time, perhaps even a number of years later, shame management capacities may prove useful in resisting or moving out of a bullying school culture.

Movement into a bullying culture was most striking in the case of nonbully-nonvictims and victims. Nonbully-nonvictims who became bullies had lower shame acknowledgment scores and higher shame displacement scores at T2 than those who remained outside the bullying culture. They appeared to slip back in adaptive shame management capacities compared with their peers who remained outside of the bullying culture, opting more readily at T2 for less owning of responsibility and more blaming of others. Homel (2009) has suggested that children who don't get along well at school are more at risk of falling behind in their capacity to adaptively manage shame. Theoretically this is in keeping with the restorative justice principle that shame is managed best when children feel safe, respected and valued. Children who are not faring well at school are likely not to feel safe enough to acknowledge wrongdoing of any kind. They might be expected to protect themselves through deflecting blame and anger onto others.

In the findings of this study, victims moved to different groups over 3 years. Of particular interest in the current study were those who moved to the bully or bully-victim 
status groups. A move toward bullying for this group was related to a perception that the school tolerated bullying. It seems likely that some victims, when faced with bullying that was not under the control of teachers, opted to join the bully culture as best they could. Those who found themselves as bullies rather than bully-victims were significantly higher than others in their displacement of shame at T2. A bullying tolerant school culture plus shame displacement typified victims who became bullies. By way of contrast, victims who became nonbully-nonvictims were less likely to describe their high school as bullying tolerant and did not identify with the shame displacement that characterized those entering the bullying culture.

Like victims who gravitated toward nonbully-nonvictim status, bullies who became nonbully-nonvictims were distinctive in being able to manage shame more adaptively and experienced a culture that was not bullying tolerant. Interestingly, however, their experience with a culture that managed bullying relatively well was at T1. Their superior shame management skills involved better acknowledgment, but this capacity was not apparent until $\mathrm{T} 2$. These children had made the break with bullying by $\mathrm{T} 2$. These data raise the question of whether in our haste to evaluate interventions we lose sight of the fact that the process of internalization and developing a moral sensibility in relation to antisocial behaviour occurs slowly. The lessons learnt in primary school about why particular behaviours are not acceptable, reinforced by effective social control, may not be taken on board in a selfregulatory way until much later, in this case, when children enter secondary school.

The other findings of interest involve children on the cusp of being a bully, but who don't make this transition, in spite of the general drift toward greater bullying in the group as a whole. Bully-victims are a group who often are considered the most at risk of harm because they have the vulnerabilities both of bullies and victims (Haynie et al. 2001; Kumpulainen and Räsänen 2000; Veenstra et al. 2005). Most stayed in the bully-victim group but some made the transition to the bully group. Those who stayed in the bullyvictim group proved to be more guilt-prone than those who 'graduated' to bully. The guiltprone finding, if it can be replicated in larger samples, may be very significant for anti-bullying and restorative justice programs. It means that a proportion of bully-victims have a deeper sense of fair play, are more able to think responsibly, and are more likely to feel remorse over doing wrong than previously recognized. This poses a particularly interesting challenge in the context of anti-bullying and restorative justice interventions. Such children don't need lessons in 'being good': These data indicate that their ideas of right and wrong may be quite well formed. Their problem may be a more practical one of being trapped, possibly with friends and allegiances to them, in an antisocial culture. These children need interventions to deliver acceptable pathways of escape so that they can practice pro-social behaviour.

Just as many bully-victims resisted escalation to the status of bully, so too did children who were involved in residual conflict. Most stayed in the residual group, but some escalated to bullying status. The factor that distinguished those staying outside of the bullying culture was their capacity to acknowledge shame over bullying at T1. Again, a principled objection to doing wrong, in this case to bullying specifically, meant that children did not get drawn further into an antisocial culture, even though movement from $\mathrm{T} 1$ to $\mathrm{T} 2$ seemed to be in the general direction of more antisocial behaviour.

\section{Implications}

The data in this paper are used to make a case for investing both in controlling external environments and teaching adaptive shame management in a bid to contain antisocial 
interactions in schools. Both elements are also present in restorative justice conferencing, but how different elements work to support the success or failure of restorativeness is yet to be investigated through experimental studies (Saulnier et al. 2011). In restorative justice conferences, as in anti-bullying programs, emotional healing through shame management is a harder objective to achieve than reparation and social control (Harris 2003). The purpose of this paper is to show that this is insufficient reason to sideline shame management or put it in the "too hard basket". Shame management that is adaptive, involving acknowledgment rather than displacement, is a personal journey of learning and integration of experiences that can be encouraged but not forced through an intervention or a conference. The data presented here demonstrate that adaptive shame management and environments conducive to pro-social norms do differentiate between those whose behaviour changes in a pro-social way and those whose behaviour does not.

Against the background of findings in this paper, the practice of restorative justice, not as an event, but as a process gains appeal. More recently, practitioners have come to refer to restorative practices (see International Institute for Restorative Practices website ${ }^{5}$ ) and restorative living (Van Ness 2011) to describe ways in which we should engage with each other in everyday life and within which restorative justice conferencing can take place. Restorative practices seek to engage effective shame management responses be it verbally or non-verbally (Bolitho 2011), not within an intervention with a clearly defined beginning and end, but in the course of daily living to deal with conflict and continually improve prosocial interpersonal skills. If shame management is as important as we contend, then its role is central to any restorative justice procedure, but also transcends any finite procedure: A single and time-limited restorative intervention program cannot be expected to adequately counter the experiences of those who have transgressed or been the victim of another's transgression. Their experiences, steeped in context and hurt, are likely to dominate their thinking long after intervention programs finish. It is only through repeated efforts to resolve conflict restoratively on a day-to-day basis, with promotion of adaptive shame management and pro-social cultural norms, that we will make meaningful inroads into the prevention of harmful behaviours.

Appendix Bullying scenarios used in the MOSS-SASD in both waves

Imagine that you are walking along the corridor at school and you see another student. You put your foot out and trip the student. Then you realize that the class teacher has just come into the corridor and saw what you did

Imagine that you have been making rude comments about a student's family. You find out that your class teacher heard what you said

Imagine that a younger student is going to the canteen to buy something. You grab his/her money. You warn the student not to tell or else. Then you realize that your class teacher saw you and heard what you said

Imagine that you are left in the classroom alone with a student. You think that the teacher has gone and so you start teasing the student. Then you realize that the teacher is still in the classroom

\footnotetext{
5 http://www.iirp.edu.
} 


\section{References}

Ahmed, E. (2001). Shame management: Regulating bullying. In E. Ahmed, N. Harris, J. Braithwaite, \& V. Braithwaite (Eds.), Shame management through reintegration (pp. 211-314). Cambridge, UK: Cambridge University Press.

Ahmed, E. (2006). Understanding bullying from a shame management perspective: Findings from a threeyear follow-up study. Educational \& Child Psychology, 23(2), 25-39.

Ahmed, E., \& Braithwaite, V. (2004a). "What? Me ashamed?": Shame management and bullying'. Journal of Research in Crime and Delinquency, 41(3), 269-294.

Ahmed, E., \& Braithwaite, V. (2004b). Bullying and victimization: Cause for concern for both families and schools. Social Psychology of Education, 7, 35-54.

Ahmed, E., \& Braithwaite, J. (2005). Forgiveness, shaming, shame and bullying. The Australian and New Zealand Journal of Criminology, 38(3), 298-323.

Ahmed, E., \& Braithwaite, V. (2006). Forgiveness, reconciliation, and shame: Three key variables in reducing school bullying. Journal of Social Issues, 62(2), 347-370.

Ahmed, E., Harris, N., Braithwaite, J., \& Braithwaite, V. B. (2001). Shame management through reintegration. Cambridge: Cambridge University Press.

Björkqvist, K., Ekman, K., \& Lagerspetz, K. M. J. (1982). Their ego picture, ideal ego picture and normative ego picture. Scandinavian Journal of Psychology, 23, 307-313.

Bolitho, J. J. (2011). Restorative justice: The ideals and realities of conferencing for young people. Critical Criminology. doi:10.1007/s10612-011-9150-z.

Braithwaite, J. (1989). Crime, shame and reintegration. Cambridge: Cambridge University Press.

Braithwaite, V., Ahmed, E., Morrison, B., \& Reinhart, M. (2003). Researching the prospects for restorative justice practice in schools: The 'Life at School Survey' 1996-9'. In L. Walgrave (Ed.), Repositioning the restorative justice: Restorative justice, criminal justice and social context. UK: Willan Publishing.

Chappell, M. S., Hasselman, S. L., Kitchin, T., Lomon, S. N., MacIver, K. W., \& Sarullo, P. L. (2006). Bullying in elementary school, high school, and college. Adolescence, 41(164), 633-648.

Espelage, D. L., Bosworth, K., \& Simon, T. R. (2000). Examining the social context of bullying behaviors in early adolescence. Journal of Counseling and Development, 78, 326-333.

Farrington, D., \& Ttofi, M. M. (2009). School-based programs to reduce bullying and victimization. Campbell Systematic Reviews, 6.

Finger, L. R., Marsh, H. W., Craveen, R. G., \& Parada, R. H. (2005). Strengthening anti-bullying research: An investigation into the misuse of dichotomous variables. Paper presented at the annual meeting of the Australian Association for Educational Research, University of Western Sydney, Parramatta, Australia.

Hanish, L. D., \& Guerra, N. G. (2004). Aggressive victims, passive victims, and bullies: Developmental continuity or developmental change? Merrill-Palmer Quarterly, 50(1), 17-38.

Harris, N. (2003). Evaluating the practice of restorative justice: The case of family group conferencing. In L. Walgrave (Ed.), Repositioning restorative justice: Restorative justice, criminal justice and social context. Cullompton: Willan Publishing.

Harris, N. (2007). Shame, ethical identity and conformity: Lessons from research on the psychology of social influence. Regulatory Institutions Network Occasional Paper 12. Canberra: Australian National University.

Haynie, D. L., Nansel, T., Eitel, P., Davis Crump, A., Saylor, K., Yu, K., et al. (2001). Bullies, victims and bully/victims: Distinct groups of at-risk youth. Journal of Early Adolescence, 21(1), 29-49.

Homel, J. (2009). Pathways from school bullying to adult aggression: A longitudinal study. Ph. D Thesis, Australian National University, Canberra.

Kumpulainen, K., \& Räsänen, E. (2000). Children involved in bullying at elementary school age: Their psychiatric symptoms and deviance in adolescence. Child Abuse and Neglect, 24(12), 1567-1577.

Kumpulainen, K., Räsänen, E., Henttonen, I., Almqvist, F., Kresanov, K., Linna, S. L., Moilanen, I., Piha, J., Tamminen, T., \& Puura, K. (1998). Bullying and psychiatric symptoms among elementary school-aged children. Child Abuse and Neglect, 22, 705-717.

Lewis, H. B. (1971). Shame and guilt in neurosis. New York: International University Press.

Nathanson, D. L. (1997). Affect theory and the compass of shame. In R. Lansky (Ed.), The widening scope of shame. Hillsdale, NJ: The Analytic Press.

O’Moore, A. M., \& Hillery, B. (1991). What do teachers need to know? In M. Elliott, (Ed.). Bullying: A practical guide to coping for schools. Harlow: Longman, UK.

Olweus, D. (1993). Bullying at school: What we know and what we can do. Oxford, UK and Cambridge: Blackwell Publishing. 
Olweus, D. (1994). Bullying at school: Long-term outcomes for the victims and an effective school-based intervention program. In L. R. Huesmann (Ed.), Aggressive behaviour: Current perspectives. New York: Plenum.

Rigby, K. (1996). Bullying in schools: What to do about it. Melbourne: Australian Council for Education Research Limited.

Rigby, K. (2002). New perspectives on bullying. London: Jessica Kingsley.

Rigby, K. (2008). Children and bullying: How parents and educators can reduce bullying at school. Malden (US), Oxford (UK) and Carlton (AUS): Blackwell Publishing.

Rigby, K., \& Cox, I. (1996). The contribution of bullying at school and low self-esteem to delinquency among Australian teenagers. Personality and Individual Differences, 21, 609-612.

Rigby, K., \& Slee, P. T. (1993). The peer relations questionnaire (PRQ). Adelaide: University of South Australia.

Saulnier, A., Lutchman, K., \& Sivasubramaniam, D. (2011). Laboratory experiments: A meaningful contribution to restorative justice research? Critical Criminology. doi:10.1007/s10612-011-9152-x.

Schäfer, M., Korn, S., Brodbeck, F. C., Wolke, D., \& Schulz, H. (2005). Bullying roles in changing contexts: The stability of victim and bully roles from primary to secondary school. International Journal of Behavioral Development, 29(4), 323-335.

Scheff, T. J., \& Retzinger, S. M. (1991). Emotions and violence: Shame and rage in destructive conflicts. Lexington, MA, USA: Lexington Books/D. C. Heath and Company.

Shin, H. (2006). A cross-cultural examination of shame management in the workplace. $\mathrm{Ph}$. D Dissertation. Australian National University, Australia.

Slee, P. T., \& Rigby, K. (1993). The relationship of Eysenck's personality factors and self-esteem to bullyvictim behavior in Australian school boys. Personality and Individual Differences, 18(1), 57-62.

Sourander, A., Helstela, L., Helenius, H., \& Piha, J. (2000). Persistence of bullying from childhood to adolescence: A longitudinal 8-year follow up study. Child Abuse and Neglect, 24, 873-881.

Tangney, J. P. (1990). Assessing individual differences in proneness to guilt: Development of the selfconscious affect and attribution inventory. Journal of Personality and Social Psychology, 59, 102-111.

Tangney, J. P., Wagner, P. E., Fletcher, C., \& Gramzow, R. (1992). Shamed into anger? The relation of shame and guilt to anger and self-reported aggression. Journal of Personality and Social Psychology, $62,669-675$.

Tomkins, S. S. (1987). Shame. In D. L. Nathanson (Ed.), The many faces of shame. New York: Guilford Press.

Van Ness, D. (2011). Restorative terminology: A modest proposal, restorative justice. Online 2 May, http://restorativejustice.org/RJOB/restorative-terminology-a-modest-proposal\#1304805140.

Veenstra, R., Lindenberg, S., Oldehinkel, A. J., De Winter, A. F., Verhulst, F. C., \& Ormel, J. (2005). Bullying and victimization in elementary schools: A comparison of bullies, victims, bully/victims, and uninvolved preadolescents. Developmental Psychology, 41(4), 672-682.

Wolke, D., Woods, S., \& Samara, M. (2009). Who escapes or remains a victim of bullying in primary school? British Journal of Developmental Psychology, 27(4), 835-851. 